\title{
À procura de um outro constitucionalismo económico: \\ construindo a cidadania a partir de iniciativas de economia solidária e popular lideradas por mulheres do Sul
}

TERESA GUNHA

ÉLIDA LAURIS

\section{Resumo}

Onde existe cidadania, existe uma constituição. No âmbito da soberania política liberal, por meio da constituição, definem-se os deveres do Estado, estabelecem-se critérios de partilha do poder e limites ao seu exercício. Um desses limites prescreve as fronteiras e as continuidades da relação entre estado e economia. Nesse sentido, enquanto a vertente liberal das constituições tende a reforçar as barreiras da intervenção do Estado na economia, as constituições sociais têm inovado o repertório de previsão de direitos económicos e sociais, bem como mecanismos para impelir a sua aplicabilidade. Neste artigo, argumentamos a necessidade de ampliar o cânone do constitucionalismo económico a partir das experiências de injustiça epistémica (Santos, 2014). A partir de baixo, isto é, das iniciativas engendradas e lideradas por mulheres no Brasil, em Moçambique e África do Sul, pretendemos trazer novos elementos de racionalidade moral e prática política que questionam os princípios subjacentes à funcionalidade económica e do progresso nacional, como está previsto nas constituições. A nossa pesquisa discute, ainda, o impacto efetivo destas socioeconomias nas mudanças sociais e no avanço da cidadania económica.

Palavras-chave: Economia. Estado. Constitucionalismo. Feminismo. África Austral

${ }^{*}$ Centro de Estudos Sociais (CES) da Universidade de Coimbra (Portugal) 
Sociologias, Porto Alegre, ano 18, no 43, set/dez 2016, p. 150-175

\title{
The quest for another economic constitutionalism: building citizenship from popular and solidarity economy initiatives led by women in the South
}

\begin{abstract}
Where there is citizenship, there is a constitution. So, State duties are defined and its limits are established. In liberal democratic canon, one of these limits prescribes a strict separation between State and Economy. Liberal constitutionalism, thus, focus on the constraints on State intervention in economy, whereas Social constitutionalism has been dedicated to the challenge of enforcing social and economic rights. In our central hypothesis we argue the need of widening economic constitutionalism having in mind experiences of epistemic injustice (Santos, 2014). From a bottom-up perspective, we mean bringing to light initiatives engendered and led by women from and in Mozambique, South Africa and Brazil that come with new rationalities to the moral and political practice, which question the founding principles of the economic functionalism and the narrative of national progress foreseen within the Constitutions. Our research discusses as well the effective impact of these socio-economies in the issue of social transformations and the advancing of economic citizenship.
\end{abstract}

Keywords: Economy. State. Constitutionalism. Feminism. Southern Africa 


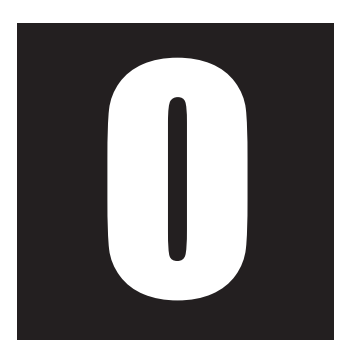

nde existe cidadania, existe uma constituição. No âmbito da soberania política liberal, por meio da constituição, definem-se os deveres do Estado, estabelecem-se critérios de partilha do poder e limites ao seu exercício. Um desses limites prescreve as fronteiras e as continuidades da relação entre estado e economia. Nesse sentido, enquanto a vertente liberal das constituições tende a reforçar as barreiras da intervenção do Estado na economia, as constituições sociais têm inovado o repertório de previsão de direitos económicos e sociais, bem como mecanismos para impelir sua aplicabilidade. Neste artigo, argumentamos que, a fim de promover a cidadania social e económica, os Estados acabam estagnados na superação do dilema liberalismo económico versus social-democracia. Neste artigo, argumentamos a necessidade de ampliar o cânone do constitucionalismo económico, a partir das experiências de injustiça epistémica (Santos, 2014). A partir de baixo, isto é, das iniciativas engendradas e lideradas por mulheres no Brasil, em Moçambique e África do Sul, pretendemos trazer novos elementos de racionalidade moral e prática política, que questionam os princípios subjacentes à funcionalidade económica e ao progresso nacional, como previsto nas constituições. Sabemos que todas as pesquisas são incompletas tal como esta o é. Neste trabalho, não tematizamos as relações destas socioeconomias com o Estado e como as aprendizagens e resistências que delas emergem se podem constituir como novas institucionalidades de poder e governo democráticos. Essa discussão, apesar de não ser feita aqui, perpassa as nossas preocupações e será levada a cabo, apropriadamente, em outro momento. Aqui, queremos colocar em relevo as subjectividades em acção destas mulheres e como elas nos abrem um campo analítico divergente com a ordem dominante. 
O primeiro elemento delimitador da funcionalidade económica do constitucionalismo reside na ideia de contrato. A fundação da comunidade política a partir da relação de direitos e deveres entre soberano e súditos. De acordo com Foucault (2005), o economismo do poder funda a soberania política ao estabelecer entre súditos e soberanos uma relação contratual. Num primeiro sentido, a funcionalidade económica da constituição expressa-se na alienação do poder e no individualismo dos direitos. Neste caso, o poder iguala-se a um bem que se pode transferir ou alienar total ou parcialmente. Num segundo sentido, o ato de alienação ou transferência do poder para os governantes, a soberania, e o resguardo de um contrapoder por parte dos súditos, os direitos individuais fundamentais, permitiu criar a sociedade política como sociedade unitária, a nação imaginada (Anderson, 1993).

Um segundo elemento da funcionalidade económica da constituição ampara-se numa narrativa de progresso, desenvolvimento e modernização. A formulação de uma historiografia progressista, que utiliza o desenvolvimento do direito como indicador do estágio civilizacional das sociedades, tem a expansão do rule of law e o transplante das democracias liberais constitucionais como pedras angulares.

A perfeita adequação do direito como metanarrativa do progresso das sociedades explica-se, ainda, pela sua utilidade na projeção universal e vanguardista da nação e do nacionalismo. A despeito da evidente existência de outros modos de organização e outras perspetivas de desenvolvimento, a experiência de imposição colonial serviu para fixar como ordem e progresso, a ordem e o progresso estabelecidos pelo imperialismo (Santos, 2009). O imperialismo não só estendeu o estado-nação enquanto modelo, como tem submetido a diversidade de nações aos seus padrões de diferenciação. 
Com a invenção do terceiro mundo e da guerra contra a pobreza (Escobar, 2007), a linha que outrora separava o trânsito de exploração entre metrópoles e colônias foi substituída por uma pista de corrida. Nesta pista, a primeira impressão é que todos terão lugar na disputa por emancipação, desde que, obviamente, sejam competentes em incrementar o seu outro lado, a regulação. A distribuição desigual entre os lugares de disputa, mantém, embora noutros termos, a conhecida separação entre selvagens e civilizados, rebatizados de doadores e recetores da ajuda internacional, consultores técnicos e assistidos.

A linha de progresso traçada pelos objetivos de modernização, crescimento económico e liberalização política para o terceiro mundo, não sendo mais colonial, é de colonialidade. Utilizamos o termo colonialidade para distinguir dois aspetos essenciais: (1) a existência de uma relação estrutural de dominação; (2) a existência de uma relação estrutural de supressão que extrai o poder de autonomeação e autodiferenciação dos sujeitos (Mohanty, 1984).

A constituição económica demoliberal corresponde aos propósitos de modernização do direito em três aspetos. Em primeiro lugar, o modelo de direito moderno resulta de normas que são invariáveis e uniformes na sua aplicação. As distinções estabelecidas pelo direito não têm em consideração qualidades intrínsecas dos indivíduos, mas diferenças funcionais, condicionais e de resultado relativas à sua posição na estrutura do Estado e nas relações sociais. Em segundo lugar, o direito moderno é transacional e tende a distribuir os direitos tal como eles resultam das transações (contratuais, de responsabilidade, criminais). Nesta lógica, a função ou a condição dos indivíduos (empregador, empregado, esposa) são mais significativas do que as noções de pertença (idoso, mulher, classe oprimida) e a performance individual é sobrevalorizada em relação ao bem-estar coletivo. Em terceiro lugar, as normas jurídicas seguem uma lógica que 
vai do particular para o universal. A singularidade dos casos particulares não interessa, na medida em que são apenas pretextos para a fixação de padrões de aplicabilidade geral.

São exemplificativas, nesse sentido, as iniciativas de combate à pobreza e legal empowerment, cuja metodologia de promoção do desenvolvimento consiste na capacitação de um homo economicus. Assim, a pobreza como manifestação estrutural do subdesenvolvimento das sociedades periféricas resulta numa dinâmica de reconhecimento oficial deficiente que deixou de fora atividades de consumo e produção que, uma vez formalizadas, poderiam ser aproveitadas em favor de funcionamento em larga escala do mercado. Nesse sentido, o legal empowement como meio de capacitação para que os pobres possam usar o direito e o sistema jurídico a fim de realizar integralmente o seu potencial humano circunscreve-se aos limites da precisa frase de De Soto (2000, p. 37): In the midst of their own poorest neighborhoods and shanty towns, there are trillions of dollars, all ready to be put to use if only the mystery of how assets are transformed into capital can be unraveled. A chave do progresso dependeria, então, de duas operações simples: (a) assegurar às/aos pobres a titulação legal da sua propriedade (caso a tenham como, por exemplo, a terra que usam e trabalham ou a casa que constroem), deixando que o acesso ao crédito faça dela/e um/a empreendedor/a e (b) reconhecer juridicamente a/o pobre como empreendedor/a informal.

Tem-se assim em consideração as necessidades jurídicas que implicam a formalização do indivíduo como trabalhador/a, consumidor/a e produtor/a, atuando principalmente nos campos da informalidade, simplificação do direito dos negócios e formalização dos direitos de propriedade.

Ao abordar a experiência e a prática do Buen Vivir, na condição de resultado da pluralidade social, cultural, económica e regional da Bolívia, Raúl Prada indaga se o Buen Vivir pode ser extrapolado nas suas dimen- 
Sociologias, Porto Alegre, ano 18, no 43, set/dez 2016, p. 150-175

sões ética e política e, assim, contribuir para uma outra visão de sociedade. Nesse sentido, defende o autor:

Buen Vivir, as the principle and goal of public policies and the foundation for both the model of the state and the economic model, is inspired by the indigenous ideal of a harmonious relationship between living beings that ensures diversity, life and the equality of redistribution.

The principles of this plenitude are:

Social solidarity, with the presupposition that human beings can only achieve such plenitude together with their fellow human beings, in other words, in community. 2. Production, the result of the interaction of communal work. 3. The reproduction of the work force and the care of the family is the responsibility of the family and the collective. 4. Complementarity, the underlying premise of the interdependence between different human beings - who have different abilities and attributes - which enriches interaction and is the foundation for common learning. 5. Production and work is done with respect for and in harmony with nature. 6. Nature is sacred and pacts with it are renewed through ritual (Prada, 2013, 146 e 147)

A relação com o futuro e os princípios de progresso e acumulação são des-pensadas ${ }^{1}$ do ponto de vista do Buen vivir, reinaugurando outras lógicas de classificação do desenvolvimento. Ainda de acordo com Prada:

- Development is no longer single or universal but plural: it is understood to be comprehensive, able to address situations that are not homogenous, and to incorporate social, political, economic and cultural aspects.

- Development is no longer merely a quantitative aim: it is a qualitative process that must consider the community's enjoyment of material goods and subjective, spiritual and intellectual realisation. Non-utilitarian trends and meanin-

\footnotetext{
${ }^{1}$ No sentido que Boaventura de Sousa Santos usa o termo: despensar como o exercício de pensar de uma maneira radicalmente nova.
} 
Sociologias, Porto Alegre, ano 18, no 43, set/dez 2016, p. 150-175

gs thus come to the fore in unison with access to services: collective enjoyment, the capacity for intercultural dialogue, cultural identity as a fundamental element for understanding what is "common".

- The accumulation of wealth and industrialisation are no longer the aims of a desirable future, but are means for attaining the harmonious co-existence between communities, and between communities with nature.

- The focus on the individual gives way to co-existence, interaction and intercultural dialogue. Co-existence between human beings becomes primary; well-being does not depend on exploiting others, less still on the cultural exclusion of the indigenous peoples. (PRADA, 2013, 148).

Seguindo a questão apresentada por Prada, neste artigo indagamos como as iniciativas de economia popular e solidária engendradas e lideradas por mulheres podem ter as suas dimensões éticas e políticas extrapoladas. Para responder a esta pergunta, analisamos aquelas iniciativas enquanto promotoras de um entendimento mínimo acerca de um bem-estar comum e socialmente partilhado. As entrevistas em profundidade e grupos focais realizados com mulheres, em Moçambique, África do Sul e no Brasil, apontam para uma reinterpretação da funcionalidade económica da constituição nos âmbitos epistemológico, político e económico ${ }^{2}$.

Epistemologicamente, nas iniciativas de mulheres em economias populares/solidárias se esvaem dicotomias como público/privado, estado/ sociedade civil, trabalho produtivo/trabalho reprodutivo, assistindo-se a outras formas de intervenção na produção e na construção de políticas

\footnotetext{
${ }^{2}$ Os excertos das entrevistas apresentadas mais adiante foram transcritos de modo a seguirem, da maneira mais próxima possível, as falas das mulheres. Nesse sentido, não foram feitos quaisquer arranjos linguísticos e gramaticais, pois as autoras consideram que estas mediações poderiam ser fatores de desvirtuamento. Este artigo, apoiado em narrativas de mulheres, considera-as como subjetividades cognoscentes que têm um valor epistemológico intrínseco. As transcrições completas fazem parte de um trabalho de pesquisa mais amplo realizado no âmbito do projecto ALICE: espelhos estranhos, lições imprevistas.
} 
públicas que, não sendo estatais, são concebidas para servir o bem comum público (Cunha, 2015).

Politicamente, as reivindicações sobre democracia deliberativa e autodeterminação dessas iniciativas transgridem os princípios da democracia liberal: uma nação, um Estado sob a autoridade de representantes eleitos. Finalmente, essas iniciativas denunciam a cumplicidade entre constitucionalismo e reprodução hegemónica do capitalismo, afirmando princípios simultâneos como não mercantilização, não rentabilidade das culturas, pessoas, bens e valores.

Ao analisarmos as reflexões que se seguem, podemos discernir que estamos perante economias em que as noções de pertença dos indivíduos, as qualidades de cada pessoa e o bem-estar coletivo permanecem complementarmente intrincados. As aprendizagens, os limites e os resultados de cada iniciativa são heranças que transcorrem dentro de cada coletivo. A sua singularidade manifesta a necessidade de ampliação e diálogo.

Deste modo e em seguida, apresentamos exemplos das iniciativas oposicionais das mulheres ao economismo do poder em três dimensões: (a) o poder como autoridade coletiva partilhada, (b) autodeterminação como experiência coletiva, e (c) dignidade como coexistência (Santos, 2009).

\section{O Poder como autoridade coletiva partilhada}

A Cidade Baixa de Porto Alegre, no Brasil, tem sido um espaço singular de realização de projetos que têm suscitado novas aprendizagens e novas convicções sobre democracia e cidadania. No caso da associação ALICE e seu jornal Boca de Rua, localizados no bairro Cidade Baixa, de Porto Alegre, as mulheres que lá trabalham como voluntárias perceberam que emancipação não é ensinar, mas sim aprender. Fazendo jus às ideias de Paulo Freire, elas chegam dos seus lugares de privilegiadas sociais e o 
forte sentido de dignidade e de pertença de um grupo de moradoras/es de rua, fazem-nas perceber que afinal é preciso fazer quase tudo de outra maneira. A sua autoridade baseia-se num sistema de partilha de poder com todas e todos do grupo. Rosina ${ }^{3}$ fala de como as e os moradores de rua que fazem com elas o jornal Boca de Rua lhes mostraram que o poder da autoridade não existe mas se conquista na interação que é profundamente democrática.

\begin{abstract}
A Alice foi uma pedra no lago. Na verdade, na verdade o BOCA foi sendo feito junto com as ideias prontas que nós trouxemos, aquele conceito que gente não confessava [mas] existia de que eu jornalista, a Marga, a Sana, nós que tínhamos tido acesso à cultura ao estudo íamos colocar nosso trabalho a serviço daquele grupo isso não era uma coisa consciente mas era isso é uma forma de subestimar o grupo. O grupo foi forte o suficiente pra nos ensinar que não e, eu acho, se existe um mérito da Alice foi de enxergar isso, não de fazer o projecto, mas enxergar isso: que o projecto tinha que ser feito junto com eles e isso pautou tudo o resto da Alice. Ela começou a trabalhar de uma forma que não é hierárquica, isso gerou uma série de problemas porque a gente não sabia fazer isso.
\end{abstract}

As aprendizagens pessoais que se transformam em sociabilidades de autoridade partilhada estão a ser, nas palavras de Rosina ${ }^{4}$, processos coletivos transformadores. Ela argumenta ainda que essas transformações acrescentam vínculos e solidariedade que tanta importância têm para as subjetividades e as sociabilidades. Ela esclarece como isso tem o seu impacto político dentro e fora da associação: todas as atividades são feitas em autogestão e a dignidade vem sempre em primeiro lugar.

\footnotetext{
${ }^{3}$ Entrevista a Rosina Duarte.

${ }^{4}$ Entrevista a Rosina Duarte.
} 
Sociologias, Porto Alegre, ano 18, no 43, set/dez 2016, p. 150-175

A Alice é viva está sempre mudando. Caminante no hay camino se hace camino al andar. A gente não tinha um modelo, entende, a gente só tinha uma vontade de fazer e nós fomos aprendendo na prática e eu acho que isso nos causou muita confusão sim, nos causou nos problemas sim, mas eu acho que isso criou um vínculo no grupo muito forte. Todos os projectos da Alice têm essa característica de autogestão. Tu traz para Alice e eles questionam e eles levam pra lá escolhem do que querem fazer porque o mesma maneira de trabalhar no Boca aplicado noutros grupos, e tem vários grupos, ela gera coisas completamente diferentes não é um macdonalds que tu bota todos iguais. Por exemplo entre as prostitutas gerou um folhetim né, uma personagem fictícia que, na verdade, tem um pouco de todas. A estrutura da Alice, ela tem uma linha que é a gente chama outras vozes que é o trabalho de produção de veículos impressos ou vídeos, ou seja lá o que for, de vários grupos, recursos de comunicação. , Já saiu de tudo, até jornal em guarda-chuva sabe, não tem ideia das coisas que saem. Se a gente fosse propor a gente não teria imaginação então, huuum, nesse ponto, volta pra a primeira linha que são as outras vozes quea partir do Boca de Rua que é o primogénito. A gente elaborou uma forma de trabalhar que é tão simples, parece tão simples mas que até a gente chegar ali foi um pouco de tendo e a gente continua tropeçando. Não é o resultado final, não é só o jornal, é toda uma maneira de enxergar o outro. Os coletes por exemplo.. Os coletes foram adquiridos com dinheiro do prémio. Eu achava que eles deveriam fazer um livro para eles venderem e eles não quiseram saber; eles queriam um colete porque todos os vendedores de jornal têm um colete só eles que não. Então não é o colete é a eles se verem como trabalhador como qualquer um e às vezes a gente custa entender isso né.

O jornal Boca de Rua é uma economia de grupo onde a expressão individual não só cabe como melhora a imaginação de todas e todos. Não é apenas uma economia simbólica onde os bens trocados são imateriais, mas também gera renda e, com ela, outros meios de dignidade e de feli- 
cidade. O Boca de Rua gera ideias, reivindicações, retratos da cidade que são olhares dissidentes e lugares de enunciação em alternativa ao discurso modelador da nação gaúcha e do seu estado Rio Grande do Sul. E tudo isso é gerado através desta autoridade coletiva partilhada que se confere em poder democrático.

É interessante continuar a pensar em poder, autoridade, mulheres e as cidades. Nas cidades, apesar dos perigos que representam em muitos sentidos para as mulheres, elas encontram espaços de poder para realizarem os seus sonhos, mas também para serem reconhecidas e poderem escolher exercer poderes públicos de grande amplitude e relevância. O trajeto de Portia Serote ${ }^{5}$ é uma singularidade que pode fixar um padrão. Pelo contrário, a especificidade do seu percurso entre as periferias miseráveis de Johannesburg, e vitimizada pelo IVH/SIDA, para a cidade, retoma a questão central desta relação entre o coletivo e o poder, como fonte de força e energia partilhadas. A sua trajetória mostra, em primeiro lugar, a sua capacidade de recusar ser apenas mais uma eternelle blessée. Ela conta como tudo começou e como, da tragédia pessoal, ela retirou a força e a autoridade para iniciar um serviço à comunidade. Porém, e mais importante do que isso, ela aprende que a produção do bem-estar coletivo é um trabalho que não pode ser levado a cabo por uma pessoa, mas sim pela comunidade.

I joined TAC 6 because after I was diagnosis with HIV in my second born, second child. My baby first was diagnosis with HIV and then, me. And then, after she was diagnosed, I tested for HIV as well and I tested positive and the father also test positive. While I was sitting down thinking that I was virgin when I found this man, he is the only man that I ever had in my whole life, how come I have HIV? Then I started sitting back and looking at women who were like

\footnotetext{
${ }^{5}$ Entrevista a Portia Serote.

${ }^{6}$ Treatment Act Campaign uma política pública da África do Sul de combate e prevenção ao HIV/SIDA.
} 
me. Because at first I was denying, saying HIV is not for me. I'm a Christian to start with, and I have been faithful to my boyfriend and he is the only one that I had ever have. How can this happen to me? I denied because my sister that time was living with HIV.

After the child was diagnosis with HIV, I said is my sister infecting my daughter? Because she used to paint her head, to hair style and many but after that, after I tested, the whole thing changed. When we looking at other women who are housewives, sitting at home, doing washings, with their boyfriends and husbands, I start to realize, and said:

- No! Something needs to be done about this. I need to stand up, I need to go to the clinics and my job specifically started with prevention because it was still a new thing, and you would never be educated when you'd go to the clinic, for you to test. And you were never forced to do so, you were never educated. Immediately after three days after being tested with HIV, and my baby girl, I took my baby at my back. I made sure that. Clinic that I attended, I stared disclosing my (...) I stared telling them how I got infected with HIV, how I didn't believe that I was infected with HIV and started telling them that HIV is not for the promiscuous ones only, but any woman, as long as you are sexually active, you can find yourself HIV positive. So, I made it a point that you test, that you get this test, and make sure that you test for HIV. At that time, I was not yet a TAC member. That was, my child now is ten years, and then after that, a few days after, you know, a few months after having done that, TAC came, and followed me to were I was staying, saying "come listen to what people are saying!" And when I got there, these people, from this office, and they don't know them, and to call people to come and listen, to what they are trying to provide. But people would not come. And then I requested them to give me the mike, and then people from Davidtown, up and running, up and down, come and listen to me tell how I got infected with HIV. And the people when they looked at me: "no! She's lying! She never had a boyfriend apart from the one that we know. She's lying! She's a Christian! She's lying!". You know, people were judging you according to what kind of a person you are, before 
that they can believe that they are HIV positive. And at the time, I was still happy as I was, but the fact that, that I was that close with HIV, after my daughter was sick for a very long time. Then people came, then they listened, then the people that came from TAC, they got interested, they wanted to know me better. Then they asked me if I don't want to join TAC. That's when I joined TAC and that's when our branch was open.

A sua capacidade como líder comunitária não seria suficiente para pensar e implementar políticas públicas. Portia Serote faz parte de uma organização, tem um sentimento de pertença muito forte a um coletivo que é, simultaneamente, o das pessoas infectadas e que querem ver a sua dignidade e saúde repostas, e aquelas que em diferentes níveis procuram inverter o estado atual das coisas no seu país a este respeito. Ela é uma Branch Organizer do programa nacional na África do Sul chamado "Treatment Action Campaign" (TAC), famoso pelas suas iniciativas públicas para encontrar soluções eficazes, como, por exemplo, o acesso aberto e gratuito aos medicamentos antirretrovirais genéricos. Ela toma a palavra e descreve assim os seus deveres públicos ${ }^{7}$ :

My work in Treatment Action Campaign (TAC). First I'm working as a branch organiser (BO). As a branch organizer my duties are to make sure that there are branch meetings that are sitting, is to make sure that I push the issues of advocacy, is to make sure that I advocate for women when they are raped, for children when they are raped and I also advocate for almost everybody to make sure that there is treatment in the clinics. And if this anything that happening that is affecting human rights is my responsibility as a $B O$.

Because in Treatment Action Campaign we speak as a human rights organization, so therefore, human rights are for everybody even women, children, men and almost everybo$d y$ within our branches. So those are my duties, as a BO, and also is to educate and to empower the branches about what are their rights so even if are not in the clinic or wherever

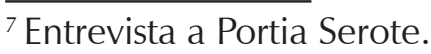


Sociologias, Porto Alegre, ano 18, no 43, set/dez 2016, p. 150-175

they could be able to stand up and fight for themselves and also to make sure that I tell them, I educate them about the policies around how to attend to court cases, what is it that they should look like, what is that they should do, how to investigating officer, in a court case were a woman or a child has been raped, what are they issues that they need to look at, as a branch organiser. And then as a national women's rep I' $m$ looking at the issues of women therefore, nationally everything that is to affect women and children is my business. Within the clinics, the policy that I implemented, I need to see to it that we put our voice as Treatment Action Campaign. So we will therefore as Treatment Action Campaign advocate for policies changes. Now we are looking at the issues of cervical cancer, European dysentery, rape, violence, all those are within my job jurisdiction.

Esta campanha, e nela também Portia Serote, tem movimentado um volume de recursos muito relevante. São recursos de todo o tipo, incluindo financeiros. A economia que é gerada pela troca e redistribuição de recursos nesta campanha, a muitos níveis, é uma economia solidária, fundada em reciprocidades que não podem, em caso algum, ser transformadas em meras mercadorias. $\mathrm{O}$ acesso a medicamentos que salvam as vidas, o diagnóstico precoce e a aprendizagem conjunta sobre a infecção e a prevenção são tudo produtos do trabalho de uma larga e diversa comunidade. Esta é uma forma de percebermos que o constitucionalismo económico, para além dos seus modelos liberais ou demoliberais, é um caminho que se vai fazendo dentro de uma nação com lugar para diversidades não controladas. O poder, aqui, é energia, força, vitalidade que, partilhado por todo o coletivo, se transforma em autoridade para se chegar à plenitude concreta dos bens comuns. 


\section{Auto-determinação como experiência coletiva}

Residente de um bairro pobre do norte da cidade de Porto Alegre, Brasil, Nelsa Nopólis congrega várias mulheres sem emprego e, com elas, inicia uma cooperativa de costureiras, a UNIVENS. Dedicam-se durante vários anos à consolidação e viabilização deste projeto, contando com a capacidade de liderança de Nelsa. As outras mulheres envolvidas reconhecem nela uma companheira e aprendem juntas a gerir encomendas e armazéns e a encontrar colaborativamente soluções para os problemas que vão surgindo. Ao longo dos anos, elas trabalham tanto dentro da cooperativa como se vão envolvendo, politicamente, em redes, em discussões e debates públicos sobre economia solidária. As suas experiências na cooperativa e a sua maturidade democrática acabam por revelar que há condições para fazer transitar uma delas para o cargo de Secretária Estadual da economia Solidária e Agricultura Familiar do Rio Grande do Sul, no Brasil.

Foi na entrevista feita na UNIVENS com algumas das cooperadas que lá trabalham, que entendemos melhor os seus percursos. Em primeiro lugar, o que parece ser de destacar é a sua capacidade de transitarem entre escalas de poder, mantendo-se ancoradas na realidade material e concreta do seu empreendimento. Essa faculdade de não prescindir, nem das suas raízes, nem da complexidade singular de cada projeto, faz uma diferença muito importante no modo como se pensam as negociações com os poderes públicos, com as outras cooperativas, com o público para quem se produzem as camisetas, sacos, vestidos e acessórios. É uma aprendizagem longa e dificultosa, mas uma autodeterminação bem-sucedida necessita, por um lado, noção de pertença e, por outro lado, a vida em comum, ou seja, autoridade partilhada. Uma das companheiras dos primórdios da UNIVENS ${ }^{8}$ analisa este percurso e põe em realce que

\footnotetext{
${ }^{8}$ Entrevista UNIVENS.
} 
uma delas, Nelsa, agora é 'delas', mas também é a Secretária Estadual da Economia Solidária. Na fala, mostra ainda que o trânsito para o poder formal de Nelsa é problemático, pois sentem sua falta e gostariam de ter a companheira de novo a tempo integral na cooperativa. A linguagem parece sugerir um conflito, pois fala-se de traição e chantagem, mas, de fato, o que está em causa é, por um lado, o sentido da urgência de voltar a juntar forças na base e, por outro lado, a consciência de que Nelsa, no momento, poderá fazer mais por todas mantendo-se no cargo que ocupa até ao final do seu mandato.

São só três as fundadoras. A Nelsa, eu e a Isaurina. Foi em 96, Maio de 96. Começou assim em Março, mas registar e tudo foi em Maio, então a gente faz 23 de Maio, todos os dias 23 e quando tem que mudar assim por assim tem que mudar, fazer eleição, é em Maio nos anos a gente muda, a gente altera as datas por algumas razões, mas se não tem, é sempre dia 23 de Maio. (...). A Nelsa (...) tá num cargo do governo do Estado, na Secretaria de Economia Solidária. Ela foi por um ano. Ela é uma traidora, eu pico ela diariamente, mas ela fez chantagem comigo, foi à minha casa e fez chantagem, isso é chantagem. Um ano, já se passaram, em Janeiro, 3, e ela vai ficar até ao último ano, tenho a certeza. Faz 3 anos, era um e a gente ficou cobrando da Nelsa, quando tu volta? e daí, não sei. E não voltou até agora, o quê ela só volta quando terminar mesmo o mandato né (..) Aí ela tinha os filhos pequenos, ela foi ao posto de saúde, bem ali perto, e ela foi no posto e ele tinha uns diretores (...) se vocês quiserem trabalhar, organizem uma cooperativa para trabalhar um grupo de mulheres ou um grupo de mães e a gente pode dar trabalho para vocês, aí a Nelsa fez uma reunião, foram 19, tinham que ser 20, mas não tinha mais e aí, na outra foram 35, aí a gente foi, formou uma cooperativa.

As formas e os métodos que recriam todos os dias, pensar em coisas novas para fazer e singrar, para liderar, para resolver ou prevenir conflitos ou resistir às dificuldades, contrariedades e dominações são questões 
que abordam e tratam, recorrentemente, nos seus discursos. Para estas mulheres, é claro que sua autodeterminação enquanto cooperativa e no seu estatuto de cooperadas não existe per se, nem se trata de um desejo individual. Elas tiveram que criar instrumentos, mecanismos, estratégias, metodologias para jogar os seus papéis no seio de diferentes articulações de poder e autoridade com que lidam. Um dos exemplos mais controversos é sobre o lugar dos homens na cooperativa. Contudo, as decisões colectivas são sempre respeitadas, assim como as suas consequências. Isaurina fala destes casos assim ${ }^{9}$ :

A UNIVENS tem o seu Amstrong: um homem, as outras são mulheres. (...). Se dependesse de mim, não teria nenhum homem, não por entendimento só de mulheres, mas a gente já tem experiência. Mas é a minha opinião, mas a maioria vota pra entrar homem, esta é só a minha opinião. Eu sou contra, porque a gente já teve vários homens aqui, o problema era bem mais grave, a gente não manda a gente pede: olha, essa serigrafia é pra hoje. Eles não admitem que a gente esteja falando isso, não sei o quê. Ai gente, a gente teve muitos problemas, então a gente teve muitos problemas, então a minha opinião é essa, aqui é que não entra mais nenhum. Tem agora um fazendo um curso aqui, mas se depender de mim, ele não vai entrar na UNIVENS, mas é como digo, a maioria vence.

Uma outra das esferas em que se comprovam as suas metodologias de autodeterminação coletiva é a da liderança no trabalho, na organização ou na família. Jacinta Jorge ${ }^{10}$ faz questão de sublinhar a importância da firmeza, da diferenciação entre as mulheres e os homens pelo uso da calma, do tempo e de palavras que não ofendem. Refere-se, também, ao assédio que as líderes devem saber perceber e desmontar numa estraté-

\footnotetext{
${ }^{9}$ Entrevista UNIVENS.

${ }^{10}$ Entrevista a Jacinta Jorge.
} 
gia de reforço da sua credibilidade e autoridade. É todo um complexo manual de procedimentos que as mulheres necessitam, para que nada possa ser usado contra elas. As sociedades, por serem patriarcais, a isso têm estado a obrigar as mulheres e elas não se escusam a interpretar e a deduzir aquilo que precisam fazer para que as suas qualidades intrínsecas pessoais fiquem ao serviço do projeto comum de emancipação.

Eu sou uma pessoa que não [me] exalto. Quando tu dás ordens a um homem ele [fica] está chateado. Eu [n]este trabalho não sei quantos nunca dá [dou] resposta no momento. Passando dois [dias] enquanto [quando] ele está mais arrefecido, mais calmo, [digo]: olha seu comportamento não foi ideal. Muitas vezes há agressividade porque [há] expressões chocantes e como homens eles se arranjam. Há coisas que até mesmo mas eu, como mulher, tenho todo cuidado de não chegar a este a este nível. Há ainda alguns [que] vem com intenções amorosas mas não porque gostam mas para denegrir fazer perder a credibilidade. Então tu que és mulher chefe tem que estar atent[a] a estas situações todas.

Um outro constitucionalismo económico, do tipo daquele que queremos dar conta aqui, não pode ser pensado sem colocar no seu centro as relações de poder, enquanto a capacidade de obrigar o outro ou de reduzir a sua à minha vontade. $\mathrm{O}$ patriarcado conjuga bem todos estes elementos e manifesta-se em todas as escalas do exercício do trabalho e da produção. De forma mais contundente ou mais subtil, o poder da autodeterminação coletiva inaugura resistências explícitas que, quando narradas pelas suas autoras, mostram a complexidade e o aparato necessário à criação de alternativas. É isto que procuramos neste experimentalismo económico de retaguarda; aquele que se constitui e apoia as lutas por vida em abundância. 


\section{Dignidade como copresença ${ }^{11}$}

Para Isaura Fernandes ${ }^{12}$, a dignidade parece ser o que realmente importa para si e o coletivo da associação (APOSEMO - Associação dos Aposentados de Moçambique) onde se insere. Para tal, realça o amor, o respeito e a igual humanidade dos seres como as principais características da liderança que ela aprecia e diz praticar. Pensa-se a si mesma como uma mulher poderosa, mas especifica que esse poder é uma força espiritual que a faz reconhecer a plena existência de todas as outras pessoas.

Porque entre nós há muito respeito, em primeiro lugar. Aqui não há diferenças de chefia ou o relacionamento. Em primeiro lugar é respeito e depois o amor entre nós. Se alguém teve um problema social, se tem qualquer coisa, nós todos vamos lá que nem formigas ajudar, apoiar, mesmo agora que não estamos a receber de nada, cada um tira ${ }^{13}$. Se não podemos apoiar muito, é uma coroa de flores dás; alguém teve isto ou não sei quê, vamos, mostramos a cara, fazemos o nosso máximo, então é isso. [Sou] poderosa espiritualmente talvez, sim, não economicamente [sou] remediada. O que é preciso é haver amor, porque eu penso [que] se houvesse tanto amor neste mundo ninguém ia conseguir matar outra pessoa, raptar, os raptos que tem havido agora isto. Se houvesse amor, eu fiquei sentida de saber as mulheres [es]tiveram metidas, duas mulheres metidas neste rapto das crianças e uma delas com um bebé. $E$ se fizessem aquilo ao bebé, foi o que pensei logo em primeiro lugar. Se tivesse acontecido isso ao bebé daquela

\footnotetext{
${ }^{11}$ Usa-se aqui o conceito de copresença no sentido que Boaventura de Sousa Santos Ihe dá ao distinguir contemporâneo e coexistente. Ele explica que a diferença reside em que duas realidades podem ser contemporâneas, porque partilham a mesma ordem linear do tempo. Porém, podem não coexistir, porque, a linha abissal que separa o que existe e o que é produzido como não existente (Santos, 2014), procede de forma a que uma tem uma ontologia própria e à outra é despojada dela para a subalternizar ou mesmo a eliminar.

${ }^{12}$ Entrevista a Isaura Fernandes.

${ }^{13}$ Esta é uma expressão usada em Moçambique para significar que tira alguma coisa de seu para dar a outrem.
} 
mulher, quer dizer, não custou ela ferir outra mulher igual? Então, eu parto do princípio que entre nós deve, devemos tirar todas a diferenças que existem e haver o amor.

A firmeza, a determinação, a serenidade, a não agressão, o sentido de oportunidade e de negociação, a espiritualidade, a oração, a empatia e a coesão são elementos que vamos identificando nas narrativas dessas mulheres quando falam dos seus empreendimentos económicos e associativos. Elas enumeram, mas também operacionalizam em exemplos, metodologias a aplicar na liderança e na resolução de conflitos, que põem em primeiro lugar a dignidade tanto da pessoa como do seu coletivo. Para além destes elementos, existem muitas outras possibilidades que elas consideram e expressam enquanto modos, capacidades e competências de resistência quotidiana às dificuldades ou à dominação mais estrutural. Elas vão identificando a paciência, o silêncio hostil, o inconformismo, a determinação, a luta em conjunto, a luta sem armas, o uso da palavra, a recusa de abandonar ou fugir, como múltiplos exemplos da força e energia implicadas nas atitudes e comportamentos das mulheres que são reconhecidas como as suas líderes. Elsa Tuzine e Albertina Raquel ${ }^{14}$, em Maputo, frisaram que é preciso determinação, novas estratégias, trabalho em grupo e enfrentar as novidades do presente sem vacilar. Mostram-se fortes, corajosas e convictas, apesar de todas as suas próprias dificuldades, quando o que está em causa é infligir uma derrota a quem as não vê na plenitude da sua coexistência.

Qualquer coisa temos que fazer para que a mulher, ou a voz da mulher, seja ouvida e seja sentida a todos os níveis. Eu acho que nós que estamos aqui, para chegar até este nível, tem que [fazer] qualquer coisa, estarmos a fazer na base. Do mesmo jeito não podemos vacilar. O caminho é à frente, mais do que ninguém ou mais do que eu, ela sabe, não vamos vacilar. Vamos combater, vamos chegar até lá.. Então nós estamos a lutar, não é por acaso que estamos aqui

$\overline{{ }^{14} \text { Entrevista coletiva. }}$ 
reunidas para poder arranjar estratégias, para poder mudar o cenário, mudar o comportamento. Mas as coisas mudaram, temos que amarrar de verdade as nossas capulanas ${ }^{15}$.

Estas mulheres esclarecem mais sobre os aspectos luminosos da sua experiência enquanto líderes e negociadoras do que sobre as suas limitações, as suas incertezas e insucessos. Questionadas sobre o que sabem e conseguem fazer, elas procuram, com os seus discursos, mostrar que os seus conhecimentos e métodos fazem sentido e são eficazes. Isto pode ser pensado como uma maneira de se interromper, de forma decisiva, as narrativas dominantes sobre as fragilidades constituintes das mulheres e, em consequência, da sua agência social.

O respeito é uma das ideias mais usadas para fazer valer a dignidade e o reconhecimento da coexistência que garante o bem-estar coletivo, em que todas e todos conseguem aceder a uma vida boa. O respeito é evidenciado como uma condição sem a qual a vida pode ser muito difícil de ser vivida e o poder de ser exercido de forma justa. As suas palavras nem sempre são cartesianamente claras, mas deixam perceber que há uma sabedoria por detrás da escolha das coisas a conservar e das coisas a mudar. Albertina Raquel ${ }^{16}$ explica que as mulheres, hoje em dia, sustentam as suas famílias sem retirar toda a autoridade aos maridos. Elas criaram, por si mesmas, um espaço de manobra e de reconhecimento que as ajuda a legitimar as transformações que desejam. Ela problematiza que a gestão doméstica ainda não é compreendida como trabalho produtivo e, por isso, não é uma responsabilidade partilhada, mas terá que sê-lo. Na eco-

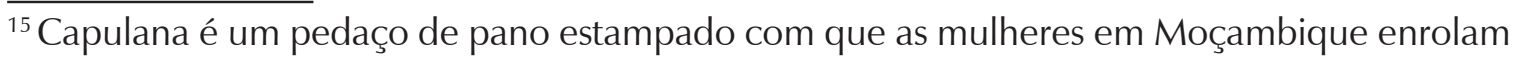
à cintura como saia ou na cabeça como lenço ou turbante. Além disso as capulanas fazem parte do dia das mulheres para decorar a casa, para os rituais de nascimento, casamento e morte e para todas as funções para as quais as achem adequadas. É um objeto da maior importância para as mulheres moçambicanas.

${ }^{16}$ Entrevista a Albertina Raquel.
} 
nomia doméstica, mulheres como Albertina Raquel vão desmantelando alguns dos pilares patriarcais: sustentar e infraestruturar a vida é um trabaIho produtivo e, por isso, é da responsabilidade da família e do coletivo.

[O]lha, o homem hoje em dia chega em casa e pergunta: o que é que fez e o que há por fazer, porque dantes não, (...) era a mulher que perguntava marido o que vou fazer! Agora não, ele pergunta o que é se fez e o que há por fazer, não porque retiramos autoridade ao homem [mas] agora a mulher faz, faz, faz muito.

\section{Notas finais}

Com este artigo, mostramos que o constitucionalismo liberal económico está assente numa ideia de Nação em que não existe lugar à diversidade, se esta não for controlável pelo Estado e pelos regimes jurídicos. Prescreve-se que as singularidades só interessam, na medida em que possam servir para a fixação de padrões aplicáveis ao conjunto da comunidade que se autoimagina una e atávica, e que o direito é uma metanarrativa da ideia do (seu) progresso. Por outro lado, as narrativas de várias mulheres de dois continentes sobre os seus trabalhos e as economias que geram vão fazendo aparecer uma metanarrativa com base em outras ordens de razão propondo outras premissas para pensar o económico e também o constitucionalismo enquanto primado da cidadania. Nomarrusia Bonase ${ }^{17}$ fala de si, ao mesmo tempo que fala dos milhares de mulheres e homens que continuam em luta na África do Sul pelo reconhecimento da sua dignidade. Mais do que isso, ela sublinha que não há vítimas, mas pessoas vitimizadas que, por meio de tudo o que aprenderam nas suas lutas contra os crimes do apartheid, são copresenças indispensáveis à administração

\footnotetext{
${ }^{17}$ Entrevista Nomarrusia Bonase.
} 
da justiça, ao desenvolvimento de uma democracia e de uma economia que tenham por finalidade o bem-estar coletivo.

Victimization took everything from us what we are saying is it make us multitalented that did give us the way to have that power that passion that activityness (...) that open so many windows because we know now we are able now to say this Act is not good, this call is good, this one must be amended (...) we must to go to the parliament to amend another Special Pension Act. I was there, I was personally in the parliament myself to put more amendments which I took from this grassroots people because they point out they ask us to bring the Act, the law and read it. When they read it the say who made this, why is like this, we must this, we must add this. The Special Act of 2008 is redone and reopened because we asked for a looking at multitalented victimhood makes us active. The governors we know they have to governor but we must direct our leaders to the right direction we are working hard to fight this South Africa a better South Africa, a beautiful one not just one talking but being practically to be the rainbow nation of South Africa. And you know an exemplary to other countries to enjoy their democracy.

Procurámos argumentar, a partir de experiências invisibilizadas e desqualificadas pelas injustiças epistémicas do liberalismo económico e da social-democracia, que a necessidade de ampliação do cânone do constitucionalismo económico não só é possível como, aliás, está operativa nas nossas sociedades. Argumentamos que o poder que sustenta uma cidadania real é multiforme e não é necessariamente a possibilidade de obrigar, disciplinar, padronizar ou reduzir os direitos à sua dimensão individual. Com os conceitos que informam as narrativas de mulheres de Moçambique, África do Sul e Brasil, colocámos em evidência novos elementos de racionalidade moral e prática política que questionam os princípios subjacentes à funcionalidade económica e ao progresso nacional, como previsto nas constituições. São eles o poder como autoridade 
coletiva partilhada, a autodeterminação como experiência coletiva e a dignidade como copresença. Para cada um deles, trouxemos argumentos ancorados nos seus contextos e nas experiências de liderança de várias mulheres, a propósito de economias de produção, mas que vão além de produção de mercadorias. São socioeconomias de renda, de coesão, de reposição da memória e da dignidade. Coteorizamos sobre o constitucionalismo económico, de forma que a nossa complementaridade enriqueça as nossas aprendizagens comuns.

Teresa Cunha é Doutora em Sociologia pela Universidade de Coimbra. Professora na Escola Superior de Educação de Coimbra, Formadora Sénior dos Centros Europeus de Juventude do Conselho da Europa e presidente da ONGD 'Acção para a Justiça e Paz'.邓 teresacunha@ces.uc.pt

Élida Lauris é Doutora em Pós-colonialismos e Cidadania Global pelo Centro de Estudos Sociais e Faculdade de Economia, da Universidade de Coimbra. É co-coordenadora do Projeto ALICE. $\measuredangle$ elidalauris@gmail.com

\section{Referências}

1. ANDERSON, B. Comunidades imaginadas. México: Fundo de Cultura Econômica, 1993.

2. CUNHA, T. Women inPower Women. Outras economias criadas e lideradas por mulheres do sul não-imperial. Buenos Aires: CLACSO, 2015.

3. DE SOTO, H. The Mystery of Capital: Why Capitalism Triumphs in the West and Fails Everywhere Else. New York: Basic Books and London: Bantam Press/ Random House, London, 2000.

4. ESCOBAR, A. La invención del tercero mundo. Invención y reinvención del desarrollo. Caracas: El perroy larana, 2007.

5. FOUCAULT, M. Em defesa da sociedade. São Paulo: Martins Fontes, 2005.

6. MOHANTY, C.T. Under western eyes: feminist scholarship and colonial discourses. Boundary 2 12/13, 1984, pp. 333-58. 
7. PRADA, R. Buen Vivir as a model for state and economy. In: LANG, Miriam; MOKRANI, Dunia (Org.). Beyond Development: Alternative visions from Latin America. Quito: Rosa Luxemburg Foundation; Amsterdam: Transnational Institute, 2013. pp.145-158.

8. SANTOS, B. de S.; MENESES, M. P. (Org.), Epistemologias do Sul. Coimbra : Edições Almedina, 2009.

9. SANTOS, B. de S. Epistemologies of the South. Justice against Epistemicide. Boulder/Londres: Paradigm Publishers, 2014

Recebido: 08.01.2016

Aceite: 01.04.2016 